\title{
PROTOTYPE WEBSITE E-COMMERCE USED CAR STUDI KASUS MOBILKUHYUNDAI.COM
}

\author{
Dani Yusuf \\ PT. Hyundai Mobil Indonesia \\ E-mail : dani.yusufia hyundai. com \\ Hand Phone : 0818972585
}

\begin{abstract}
Electronic Commence (e-Commerce) sangat mendukang dalam peninghaian pengembangan, suatu perusahaan. Dengan adanja e-commerce akan dapat memberikan suafu kelajakan bagg pihak manajemen dalam memproses berbagai sumberdaya yang digunakan. Diantara sumberdaya tersebut, e-cammerce merupakan pendukang manajemen dalam proses pemasaran untuk mencapai tujuan. Hal tersebut dikarena e-commerce dapat menubah bentuk pelayanan yang semula harus datang langsung ke suatu instansi yang dituju ataupun melalui via telepon, sapi sekarang menjadi pelayanan yang online disetiap wakiu dimanapun berada sehingga dapat memudahkan dalam menangani segala

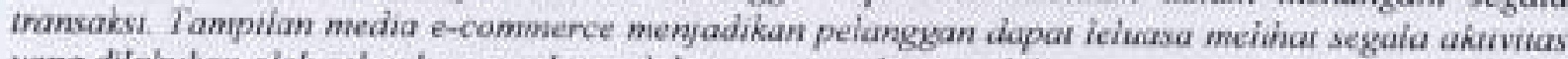
yang dilakukan oleh sebuah perusahaan dalam memasarkan produknya.

Pemasaran terbentuk harena adanya aset yang unik sehingga menjadi sebuah jaringan pemasaran yang terdiri dari perusahaan dan pemercaya (stake horder) pentukung, karyasan, pemasok distribusi, pengecer, agen periklanan dan sebagainya seiring dengan langkah perusahaan membangun hubungan timbale balik yang saling menguntungkan. E-commerce dengan manajemen purusahaan sangat erat kaitannya, karena disini e-commerce berperan sebagai sarana pendukung pemasoran untuk menyampaikan informasi demi mencapai tujuan.
\end{abstract}

Kata-kunci : e-commerce, bursa mobil

\section{PENDahuluan}

\subsection{Latar Belakang}

Perkembangan teknologi informasi dewasa ini semakin pesat terutama dengan kehadiran internet yang penomenal yang membawa angin segar dalam penyajian informasi yang lebih eepat dan efisien. Proses penjualan barang sebagai penunjang kegiatan operasional sebuah perusahaan perlu mendapatkan perhatian khusus karena saat ini, persaingan dalam dunia usaha semakin ketat. Para pesaing yang mempunyai business model yang sangat cepat sekali datang dengan membawa keunggulankeunggulan yang lebih banyak. Hampir mastahil untuk dapat mempertahankan suatu business model dalam kurun waktu lama. Untuk itu maka para pelaku bisnis dituntat untuk semakin kritis dan jeli dalam menganalisa kebutuhan pasar. Mereka dituntut untuk dapat mengambil keputusan-keputusan yang tepat dan cepat dalam membawakan bisniss model mereka.
Hal-hal tersebut diatas berlaku untuk semua bisniss model, termasuk diantaranya bisniss model yang mulai dikembangkan dengan electronic Commerce (e-Commerce) eCommerce merupakan kebutuhan penting saat ini dalam dunia bisnis global, dan sebagai penunjang dalam pengembangan pasar. meningkatkan efisiensi, dapat menekankan biaya, serta memberikan akses yang lebih luas bagi parmer dan pelanggan. e-Commerce timbul akibat pesatnya kemajuan Information Technology yang sejalan dengan perkenbangan zaman yang mengubah hampir seluruh sendi-sendi kehidupan. e-Commence memiliki fleksibilitas dan keunikan bagi setiap perusahaan, karena perusahaan memiliki perbedaan dalam pengambangan IT serta kebutuhan akan model teknologi informasi bagi bisnisnya.

Perancangan website e-Commerce mobil bekas Hyundai akan menggunakan bahasa pemrograman PHP dengan dukungan database MySQL. Perangkat lunak ini berbasis open 
source yang dapat diunduh di internet. Sistem ini akan bekerja di bawah sistem operasi LINUX dan bebasis client-server. Pengembangan e-Commerce online ini akan mempertemukan antara pejual dengan pembeli mobil bekas merk Hyundai, dan bagi perusahaan hal ini dapat meningkatkan keuntungan bagi karena perusahaan dapat juga langsung melakukan penawaran untuk membeli kendaraann yang dijual oleh pemiliknya segaligus menawarkan untuk mengganti dengan kendaraan Hyundai yang baru.

\subsection{Permasalahan Penelitian}

PT. Hyundai Mobil Indonesia (HMI) adalah Agen Tunggal Pemegang Merk (ATPM) Hyundai. Di Indonesia, konsumen pertama kali mengenal kendaraan Hyundar pada tahun 1995 melalui produk Elantra (Bimantara Nenggala) yang dirakit oleh PT. Hyundai Motor Indonesia (HIM) dengan pabriknya yang berlokasi di Jl. Wahab Affan, KM. 28 Pondok Ungu Bekasi dan dipereayakan pemasarannya oleh PT. Hyundai Mobil Indonesia yang berkantor pusat di JI. Sultan Iskandar Muda No. 81, Arteri Pondok Indah, Jakarta Selatan.

Dari sejak pertama berdin sampai sekarang ini. Hyundai Indonesia sudah menjual produknya baik dalam bentuk CKD (Complete Knock down) maupun CBU (Complete Built Uip). Sampai saat ini Hyundai di Indonesia sudah mengeluarkan beberapa model kendaraan mulai dari segmen pasar low sampai dengan segmen high

Selama ini Autosafe kesulitan dalam mengembangkan bisnis mereka dikarenakan terhatasnya informasi keberadaan Autosafe di Indonesia, sehingga promosi hanya mengandalkan konsumen yang datang ke outlet cabang-cabang mereka. Seringkali Autosafe juga mengalami kesulitan untuk menyediakan stok mobil Hyundai dagangan mereka, kerena keberadaan pernilik Hyundai yang ingin menjual kendaraan sangat sulit diketahui.

Penelitian dilakukan dengan menggunakan metode penelitian Deskriptif Kualitatif dengan studi kasus yang bertujuan untuk mendapatkan gambaran yang lebih mendalam dan leagkap dari subyek yang akan diteliti. Pengumpulan data dan informasi disini sangat terkait dengan user requirentent yang akan memanfaatkan eCommerce. Data dan informasi diperoleh dari data primer dan data sekunder. Data primer, diperoleh dengan melakukan wawancara dan observasi tentang model e-Commerce. Sedangkan data sekunder diperoleh melalui studi pustaka, yaitu melalui studi literatur dan tulisan ilmiah tentang e-Commerce. Penelitian ini mengambil tempat di salah satu cabang Autosafe Hyundai bertempat di $\mathrm{J}$. Raya Kalimalang, Billy \& Moon B] Bekasi. Telp. (021) 8656868 .

\subsubsection{Identifikasi Masalah}

Bagamana membangun perangkat lunak proplotype website e-Commence used car yang berkualitas yang dapat memberikan kepuasan baggi penggunanya dengan menggunakan pendekatan model waterfall dengan runtut tahapan Soffware requirements anaiysis, Design, Code generation, Tesung,

\subsubsection{Ruang Lingkup Masalah}

Untuk dapat menyelesaikan penelitian tepat waktu dan dengan sumberdaya yang terbatas, maka permasalahan yang akan dibahas harus dibatasi. Batasan masalah tersebut adalah :

a. Pada penelitian ini lebih ditekankan kepada interaktif antara penjual dan konsumen dalam melakukan belanja secara online.

b. Pada pembuatan prototiype dan aplikasi tidak dibahas cara melakukan transaksi secara online.

c. Sasaran pengguna aplikasi e-Commerce adalah kalangan pengguna internet pernilik kendaraan Hyundai, Pedagang atau pemilik kendaraan yang ingin menjual atau membeli kendaraan Hyundai dan konsumen yang hendak membeli kendaraan bekas merk Hyundai.

\subsubsection{Rumusan Masalah}

Terkait dengan berbagai masalah dan pemanfaatan website e-Commerce used car ini, 
maka rumusan permasalahan yang menjadi dasar untuk melakukan penelitian ini, yaitu :

a. Perlunya untuk mengetahui model pendekatan waterfall dalam membangun aplikasi e-Commence memanfaatkan teknologi internet.

b. Perlunya meneliti faktor-faktor yang berpengaruh terhadap kepuasan penggunaan website e-Commerce, sehingga dapat diketahui permasalahanpermasalahan dalam proses pembuatan websife e-Commerce.

\subsection{Tujuan dan Manfaat Penelitian}

Suatu penelitian sudah tentu harus mempunyai tujuan dan manfaat penelitian, untuk itu disini akan dijelaskan mengenai tujuan dan manfaat penelitian ini

\subsubsection{Tujuan Penelitian}

Tujuan yang ingin dicapai dan penelitian ini adalah.

a. Memberikan kemudahan bagi pemilik kendaraan Hyundai untuk menjual kendaraannya secara online melalui media web.

b. Memberikan kemudahan bagi pencari mobil bekas yang ingin membeli

c. kendaraan merk Hyundai baik secara kontak maupun kredit, sehingga tidak perlu lagi datang ke showroom-showroom mobil

d. Mernberikan informasi harga suku cadang asli dan jaringan service Hyundai kepada pemilik kendaraan merk Hyundai.

\subsection{Manfat Penclitian}

Diharapkan prototype website e-Commerce used car ini dapat membcrikan manfaat sebagai berikut:

a. Kendaraan merk Hyundai bisa lebih di kenal lagi secara luas oleh masyarakat Indonesia.

b. Bagi penulis, penelitian ini digunakan untuk menambah wawasan dan ilmu pengetahuan di bidang teknologi informasi, sebagai sarana dalam menerapkan teori-teori yang telah dipelajari selama masa perkuliahan dan melatih berfikir kritis dalam melakukan analisis permasalahan yang berkenaan dengan teknologi informasi, khususnya mengenai tingkat penerimaan teknologi informasi bagi pengguna.

c. Memberikan informasi kepada pembaca mengenai bentuk e-Commerce yang dibuat.

\subsection{Tinjauan Pustaka}

Dari berbagai hal yang didapatkan terhadap pembahasan penelitian ini, tinjauan pustaka yang diolah didalamnya menjadi kesatuan pokok pembahasan untuk mendukung literatur agar tidak lepas dari pokok pembahasan. Beberapa tinjauan pustaka yang digunakan dalam penelitian ini adalah materi perkuliahan, buku cetakan, e-book dan tulisan ilmiah yang berkaitan dengan pokok pembahasan utama yaitu website dan e-commerce.

\subsection{Landasan Teori}

Merupakan suatu penjelasan tentang sumber acuan terbaru dari pustaka primer seperti artikel, jurnal, monograf, dan tulisan asli lainnya untuk mengetahui perkembangan penelitian yang relevan dengan judul atau tema penelitian ini dan juga sebagai arahan dalam memecalkan masalah yane diteliti.

\subsubsection{Pengertian WWW}

WWW sdalah kependekan dari World Wide Web yaitu halaman-halaman website atau dokumen yang dapat saling terkoneksi satu desgan lainnya (hyperlink) yang membentuk samudra belantara informasi. Halaman Web merupakan file teks murni (plain text) yang berisi sintaks-sintaks HTML (HyperTexi Markup Langwage) yang dapat dibuka, dilihat dan diterjemahkan dengan Intemet Browser. Sintaks HTML mampu memuat konten gambar, audio, video dun animasi

Penggunaan website yang baik akan sangat mempengaruhi kesuksesan perusahaan dalam 
mengelola bisnisnya dimana aplikasi website yang akan digunakan dspat dibuat sendiri (make) atau dibeli (buy) melalui pihak ketiga (outsourcing). Contoh, web agency dan web advice site, yaitu BaseSync telah membantu OP4.com's dalam menentukan tujuan dari aplikasi website-nya sebagai berikut (Huff, Sid L., 2002:p12).

\subsubsection{Web Engineering}

Web engineering (rekayasa web) adalah suatu proses yang digunakan untuk menciptakan suatu sistem aplikasi berbasis web dengan menggunakan ilmu rekryasa, prinsip-prinsip manajemen dan pendekatan sistematis sehingga dapat diperoleh sistem dan aplikasi web dengan kualitas tinggi: Pada dasamya pemrograman web ditujukan untuk menyampakan informasi kepada user, dengan memanfaatkan teknologi jaringan berbasis protokol TCP/IP.

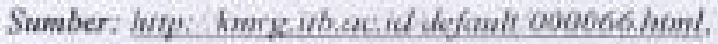

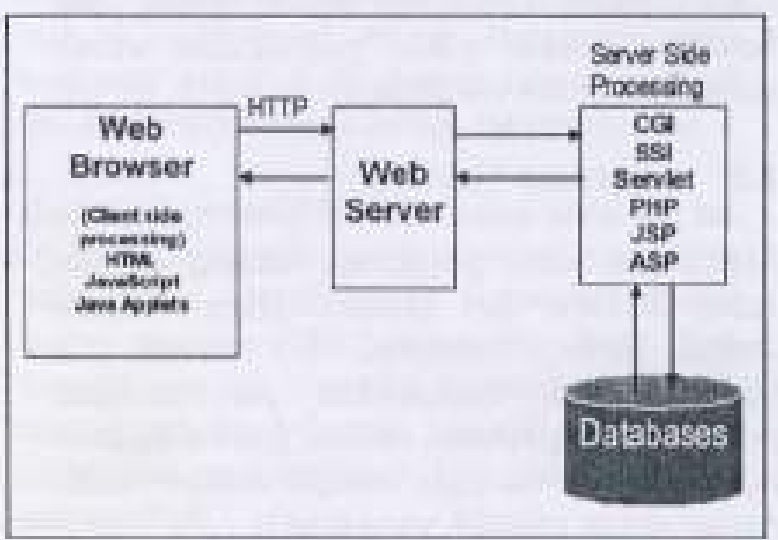

Gambar 1. Penrosesan Scripl Program

\subsubsection{Pengertian e-Commerce}

Definisi dari "e-Commerce " sangat beragam tergantung dari perspektif atau kacamata yang memanfaatkannya (Richardus Eko Indrajit. 2001:p35).

a. Association For Electronic Commece secara sederhana mendefinisikan eCommerce sebagai "mekanisma bisnis secara dectronic"

b. CommerceNet, sebuah konsorsium industri, memberikan definisi yang lebih lengkap, yaitu "penggunakan jejaring komputer (Komputer yang bisa saling bertubungan) sebagai sarana penciptaan relasi bisais". CommerceNet menambahkan bahwa didalam eCommerce terjadi "proses pembelian dan penjualan jasa atau produk antar dua belah pihak melalui internet atau pertukaran dan distribusi informasi antara dua puhak dalam satu perusahaan dengan menggunakan internet ".

c. Sementara Amir Hartman dalam bukunya "Net-Ready" (Amir Hartman, 2000;p34) secara lebih terperinci lagi mendefinisikan e-Commerce sebagai "suatu jenis dari mekanisme bisnis secara eleltronis yang memfokuskan diri pada transaksi bisnis berbasis individu dengan menggunakan internet sebagai medium pertukaran barang atau jasa baik antara dus buah institusi (Business to busmess) maupun antar institusi dan konsumen langsung (Business to Customer)".

d. Beberapa kalangan akademis pun sepakat mendefinisikan e-Commerce sebagai "salah satu cara memperbaiki kinerja dan mekanisme pertukaran barang. jasa, informasi, dan pengetahuan dengan memanfaatkan teknologi berbasis jaringan peralatan digital".

e-Commerce menggambarkan proses pembelian, penjualan, pemindahan ataupun pertukaran produk, jasa atau informasi melalui jaringan komputer, termasuk internet.

Hampir seluruh aktivitas komersil, pendidikan, pemerintahan dan sebagainya menggunakan aplikasi web. e-Commerce, adalah merupakan transaksi komersil yang dilakukan melalui web, telah menghasilkan banyak keuntungan, sebagaimana dukungan atas kebutuhan hardware dan sofware atas website dan transaksi e-Commerce tersebut. Jenis aktivitas e-Commerce melalui website adalah the business-to-ctustomer (B2C) sector e-retailing. the business-to-business (B2B) sector melakukan transaksi atas perusahaan, dan the customer-to-customer $(\mathrm{C} 2 \mathrm{C})$ sector.

Sementara menurut sumber lainnya eCommerce berarti membeli atau menjual secara elektronik dan keinginan ini dilakukan pada jaringan intemet (Riyeke Ustadiyanto, 2001:p14) 
Dari masing-masing definisi diatas terdapat kesamaan dimans e-Commerce memiliki beberapa karakteristik yaitu :

a. Terjadinya transaksi antara kedua belah pihak.

b. Adanya pertukaran barang jasa atau informasi.

c. Menggunakan internet sebagai medium utama dalam proses atau mekanisme perdagangan tersebut.

\subsubsection{Pengertian e-Commerce}

Definisi dari "e-Commerce " sangat beragam tergantung dari perspektif atau kacamata yang memanfaatkannya (Richardus Eko Indrajit, 2001:p35).

a. Assaciation for Electronic Commecte secara sederhana mendefinisikan $e$ Commerce sebagai "mekanisma bisnis secara electronic

b. Commerce:Net, sebuah konsorsium industri, memberikan definisi yang lebih lengkap, yaitu "penggunakan jejaring komputer (Komputer yang bisa saling berhubungan) sebagai sarana penciptaan relasi bisnis". CommerceNet menambahkan bahwa didalam eCommerce terjadi "proses pembelian dan penjualan jasa atau produk antar dua belah pihak melalui intemet atau pertukaran dan distribusi informasi antara dua puhak dalam satu perusahaan dengan mengguaakan intemet ".

e. Sementara Amir Hartman dalam bukunya "Net-Ready" (Amir Hartman, 2000:p34) secarn lebih terperinci lagi mendefinisikan e-Commence sebagai "suatu jenis dari mekanisme bisnis secara eleltronis yang memfokuskan din pada transaksi bisnis berbasis individu dengan menggunakan internet sebagai medium pertukaran barang atau jasa baik antara dua buah institusi (Business to business) maupun antar institusi dan konsumen langsung (Business to Customer)".

d. Beberapa kalangan akademis pun sepakat mendefinisikan e-Commerce sebagai "salah satu cara memperbaiki kinerja dan mekanisme pertukaran barang jasa, informasi, dan pengetahuan dengan memanfaatkan teknologi berbasis jaringan peralatan digital".

\subsubsection{Mekanisme Kerja e-Commerce}

Mekanisme kerja e-Commerce terlihat pada gambar di bawah ini : (Richardus Eko Indrajit, 2001p16)

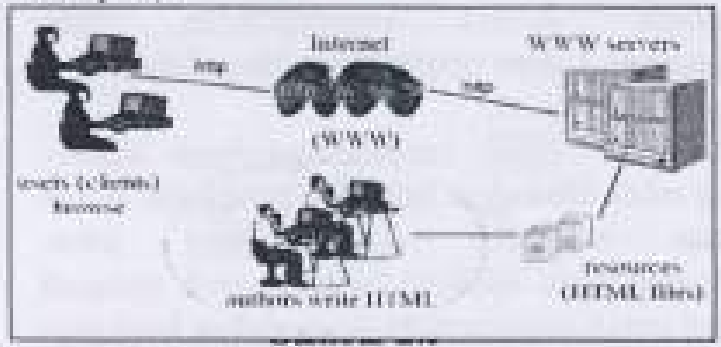

Mekanisme Kerja e-Commerce

Ada dua hal utama yang biasa dilakukan oleh konsumen (Custommers) di dunia maya. Pertama adalah melihat produk-produk atau jasa-jasa yang diiklankan oleh perusahaan terkait melalui website-nya (Online $A d s$ ). Kedua adalah mencari data atau informasi tertentu yang dibutuhkan sehubungan dengan proses transaksi bisnis atau dagang (jual beli) yang akan dilakukan.

\subsection{Kerangka Pemikiran}

Merupakan suatu penjelasan tentang kerangka berpikir kesisteman untuk memecahkan masalah yang sedang diteliti. Adapun diagram kerangka pemikirannya adalah sebagai berikut:

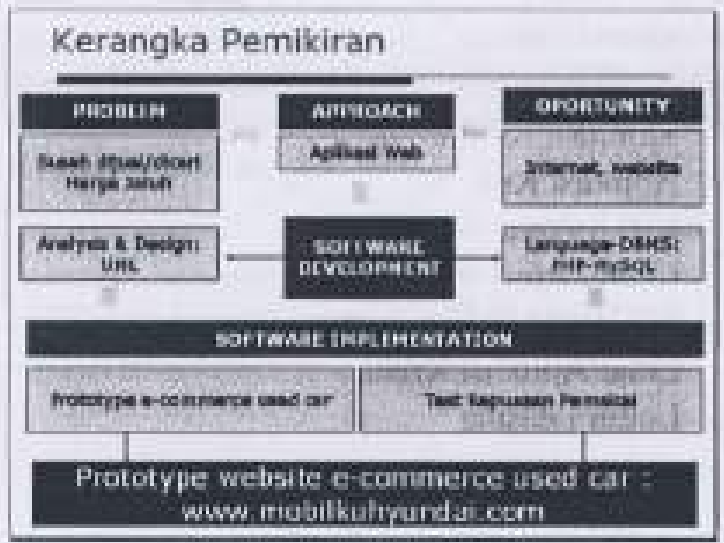

Gambar 2. Kerangka Pemikiran

\section{Metodologi Penelitian}

\subsection{Analisis Kebutuhan}

Analisa kebutuhan merupakan tahapun penting dalam membangun suatu petangkat lunak, karena berkatan dengan kebutuhan sistem secara keseluruhan, maka kegagalan 
memenuhi kebutuhan jenis ini berakibat pada sistem secara keseluruhan. Contoh kebutuhan jenis ini adalah kecepatan akses, keamanan data, besarnya kapasitas penyimpanan yang diperlukan, privasi masing-masing profil /account, bahasa pemrograman yang digunakan, sistem operasi yang digunakan.

Kebutahan sistem berdasarkan hasil analisa yang telah dilakukan terhadap pengguna sudah cukup memadai dan sangat jelas. Pengembangan aplikasi berbasis web menjadi solusi untuk memberikan kemudahan bagi user (penjual, pembeli dan penyedia jasa leasing kendarasn Hyundai) untuk melakukan tugas atau aktivitasnya yang terintegrasi dan bekerja dengan satu platform berbasis web,

\subsubsection{Pengguna Sistem}

Para pengguna sistem website e-commerce used car dapat dijelaskan di sini yang direpresentasikan sebagai aktor.

\subsubsection{Fitur-fitur Pada Sistem}

fitur-fitur atau fungsi pada sistem yang diminta secara keseluruhan dapat dijelaskan sebagai berikut::
a. Login Penjual
b. Input Iklan
c. Update Iklan
d. Lihat Iklan
e. Simulasi Kredit
f. Aplikasi Kredit
g. Kirim Pesan
h. Lihat Jaringan Service
i. Lihat Harga Suku Cadang
j. Lithat Aplikasi Kredit
k. Login Leasing

\subsection{Perancangan Penelitian}

Metode yang digunakan dalam analisis dan perancangan pada prototype website ecommerce used car adalah metode waterfall. Metode ini membagi proses pembanguman perangkat lunak kedalam fase-fase individu atau langkah-langkah. Fase atau langkah yang satu dengan yang lainnya terpisah secara kronologis dan fungsional.

Model waterfall merupakan salah satu dari model-model yang terdapat pada penerapan
Daur Hidup Pengembangan Sistem. Roger.S, Pressman (2001:p57) membagi model Waterfall ke dalam beberapa tahap, yaitu: tahap rekayasa sistem, analisis kebutuhan perangkat lunak, perancangan, pemrograman, pengujian, dan pemeliharaan yang dapat digambarkan pada gambar berikut:

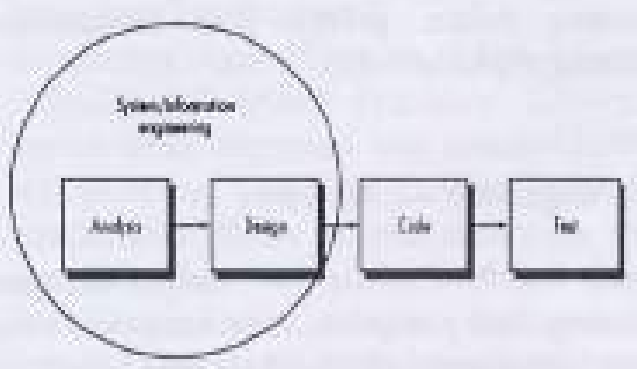

Ganbar 3. Skema modol waterfall

\section{Desain Sistem}

Desain sistem dalam perancangan prototype website e-commerce used car ini menggunakan UML (Unified Modeling Language) yaitu suatu metode modeling generasi ketiga dan bahasa spesifikasi yang sifatnya noaproprietary. Sebenarnya penggunaan dari UML itu sendiri tidak terbatas hanya pada dunia sofhware modeling, tetapi bisa pula digunakan untuk modeling hardware (engineering systems) dan sering digunakan sebagai modeling untuk proses bisnis dan juga modeling untuk struktur organisasi.

Perancangan prototype website encommerce used car hanya menggunakan beberapa jenis standar diagram UML saja karena dianggap sudah mencukupi untuk menyelesaikan kasus ini:
a. Use case diagram
b. Class Diagnam
c. Sequence diagram
d. Actwity diagram

\subsubsection{Use Case Diagram}

Setelah selesai pada tahap analisa kebutuhan sistem, dan keinginan user sudah dipahami dengan benar, maka tahap berikutnya adalah menterjemahkan prototype website econmerce used car ke dalam bentuk use case diagram untuk menjelaskan gambaran sistem dan aktor yang terlibat secara keseluruhan, Berbeda dengan class diagran yang lebih 
cocok dibaca oleh disainer/analis, use case diagram sangat cocok untuk dipahami oleh pemesan/pengguna sistem. Selain itu use case diagram hanya menggambarkan apa yang dilakukan oleh sistem dan tidak menggambarkan bagaimana sistem melakukannya Komponen use case diagram terdiri dari : Actor, use case dan relation. Aktor adalah pemain, sedangkan use case adalah apa yang dimainkan/dilakukannya dengan relation sebagai penunjuknya.

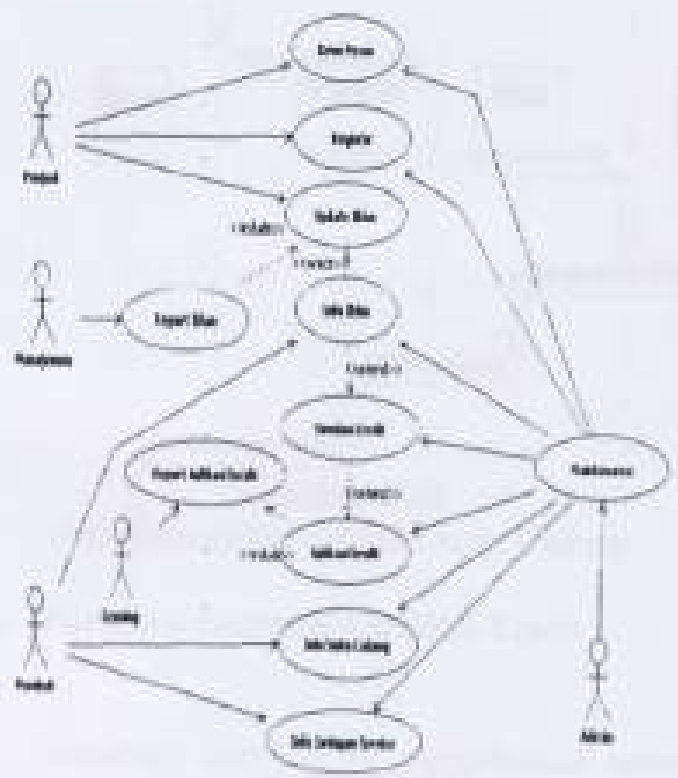

Gambar 4. Use Case Prototype Websine eCommerce Used Car

\section{Class Dlagram}

Setelah kita membuat usecase diagram, langkah selanjutnya adalah membuat Class Diagram berdasarkan usecase diagram tersebut. Class diagram ini barus berisikan objek-objek yang terdapat di dalam web ecommerce used car ini. Berdasarkan pada kasus tersebut, fokus utama pada kasus ini adalah pemasangan iklan dan pembelian kendaraan yang diiklankan secara kredit. Berikut adalah diagramnya.

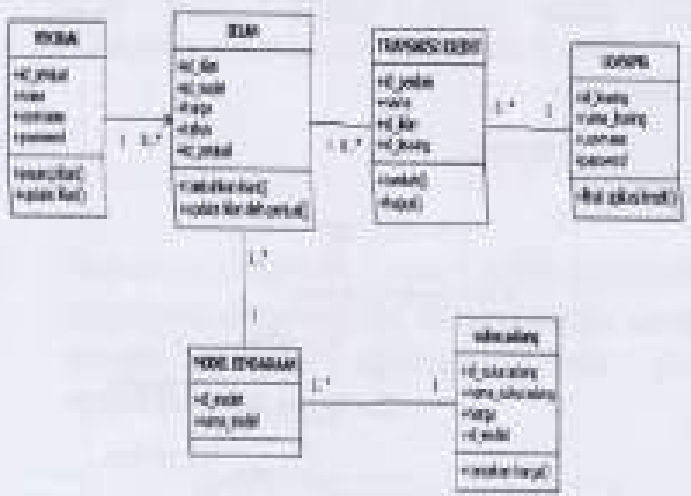

Gambar 5. Class Diagram Prototype Website eCommerce Used Car

\section{Sequence Diagram}

Sequence diagram menjelaskan interaksi antar obyek yang disusun dalam suatu urutan waktu yaitu urutan kejadian yang dilakukan oleh seorang actor dalam menjalankan sistem. Diagram ini secara khusus berasosiasi dengan use case, Diagram ini menunjukkan bagaimana detil operasi dilakukan, pesan apa yang dikirim dan kapan terjadinya.

Berikut adalah rancangan sequence diagram yang dipetakan dari obyek-obyek yang ada pada class diagram sebelumnya.

a. Sequence Diagram Register

Sequence diagram ini menjelaskan urutan proses seorang penjual untuk mendaftar menjadi member sehingga sehingga nantinya member ini dapat memasang, merubah serta menghapus iklannya.

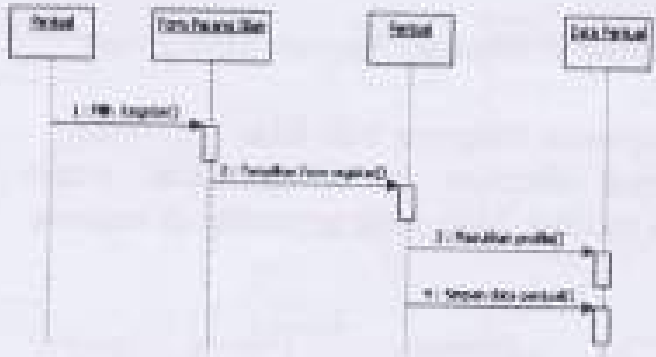

Gambar 6. Serquence Diagram Register

b. Sequence Diagram Update Iklan

Sequence diagram ini menjelaskan urutan proses update iklan oleh penjual yang telah menjadi member seperti menambahkan, merubah atau menghapus iklan yang telah laku terjual. 


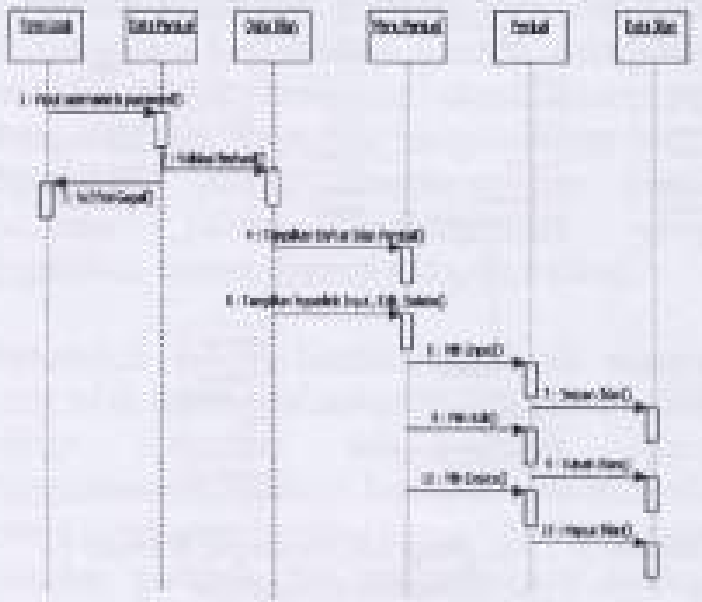

Gambar 7. Sequence Diagram Update IRlan

c. Sequence Diagram Kirim Pesan

Sequence diagram ini menjelaskan urutan proses pengiriman pesan dari penguajung ke administrator, yang akan dijawab olelinya melalui email oleh sistem.

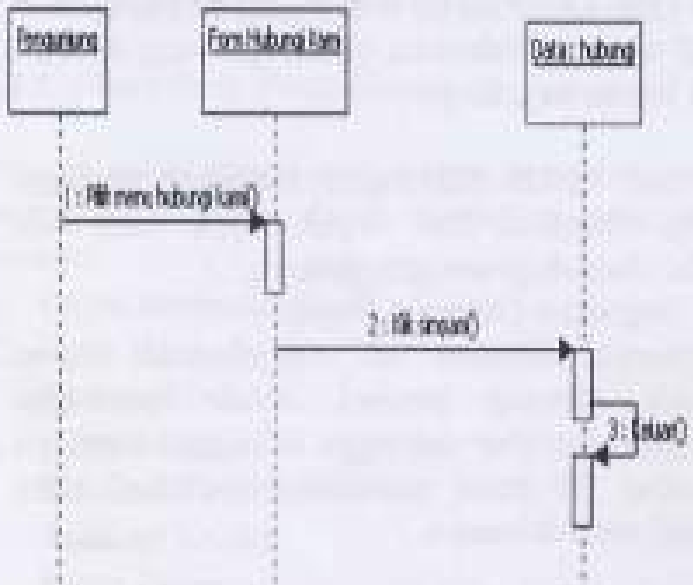

Gambar 8. Sequence diagram Kirim Pesm

d. Sequence Diagram info Iklan

Sequence diagram ini menjelaskan urutan proses melihat iklan yang terpasang di website

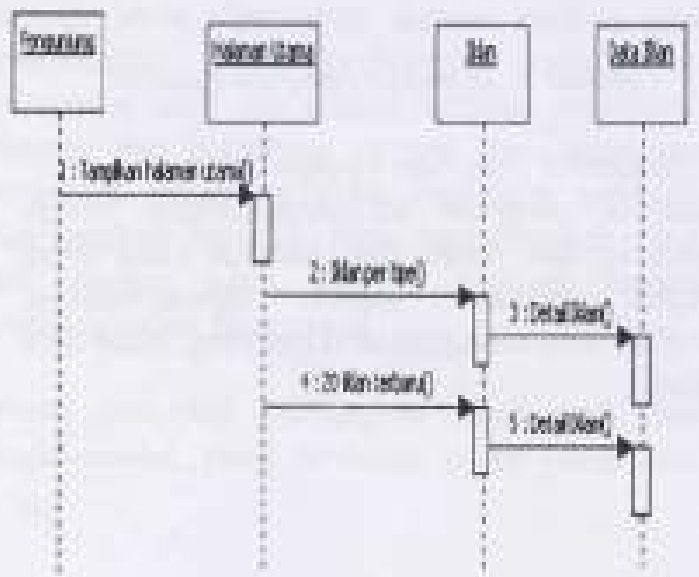

Gambar 9. Sequence Diagram info Iklan

e. Sequence Diagram Aplikasi Kredit

Sequence diagram ini menjelaskan urutan proses pengajuan aplikasi kredit yang dilakukan oleh calon pembeli yang ingin membeli kendaraan yang diiklankan secara kredit.

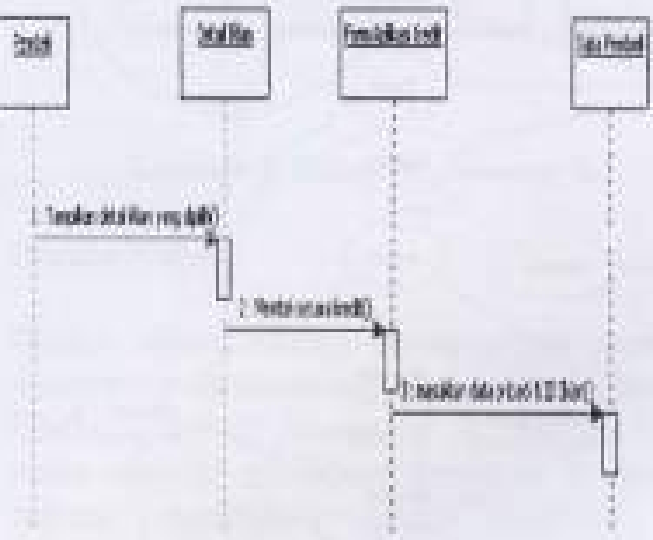

Gambar 3.8

Sequence Diagram Aplikasi Kredit

f. Sequence Diagram Info Jaringan Service Sequence diagram ini menjelaskan urutan proses menampilkan jaringan service Hyundai yang diminta oleh pengunjung .

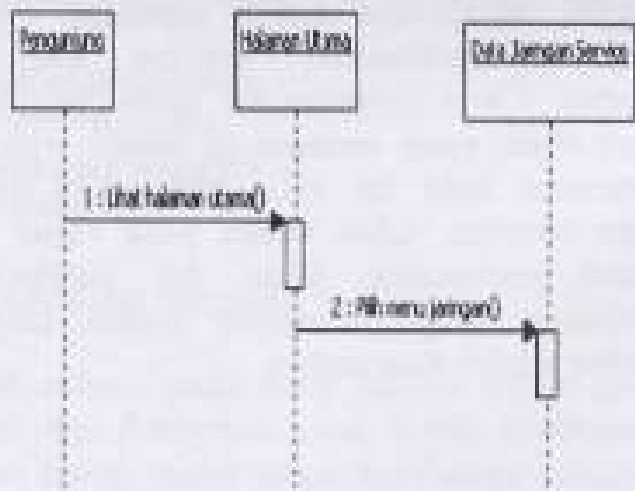

Gambar 3.9

Sequence Diagram Info Jaringan Service 
g. Sequence Diagram Info Suku Cadang. Sequence diagram ini menjelaskan urutan proses menampilkan jaringan service Hyundai yang diminta oleh pengunjung .
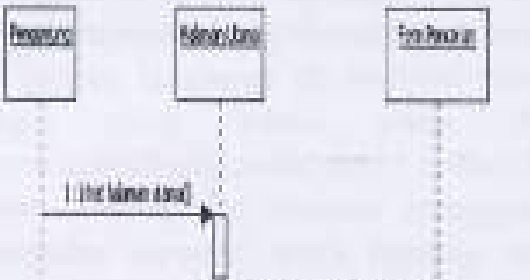

2xitakiogabalet

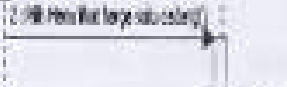

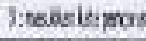

Gambar 3.10

Sequence Diagram Info Suku Cadang

h. Sequence Diagram Simulasi Kredit

Sequence diagram ini menjelaskan urutan proses simulasi kredit yang dilakukan olch pengunjung website untuk memperoleh informasi mengenai cicilan dan uang muka yang harus dibayarkan apabila pengunjung ingin membeli kendaraan secara kredit.

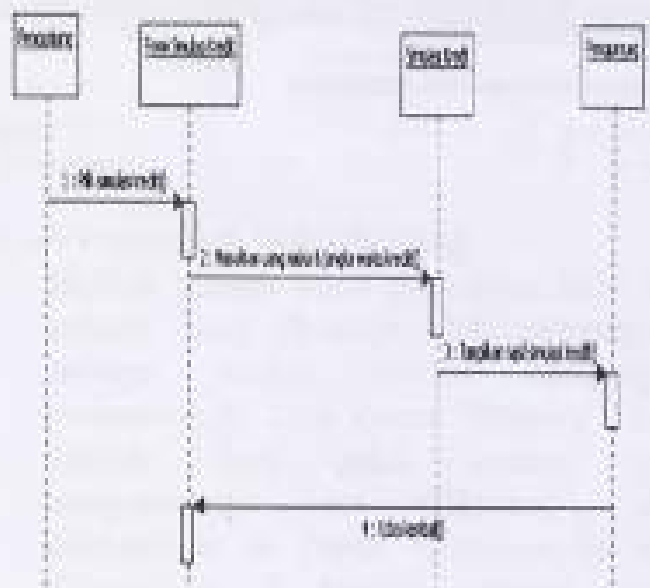

Gambar 3.11

Sequence Diagram Simulasi Kredit

i. Sequence Diagram Report Aplikasi Kredit Sequence diagram ini menjelaskan urutan proses melihat aplikasi kredit yang diajukan oleh pembeli.

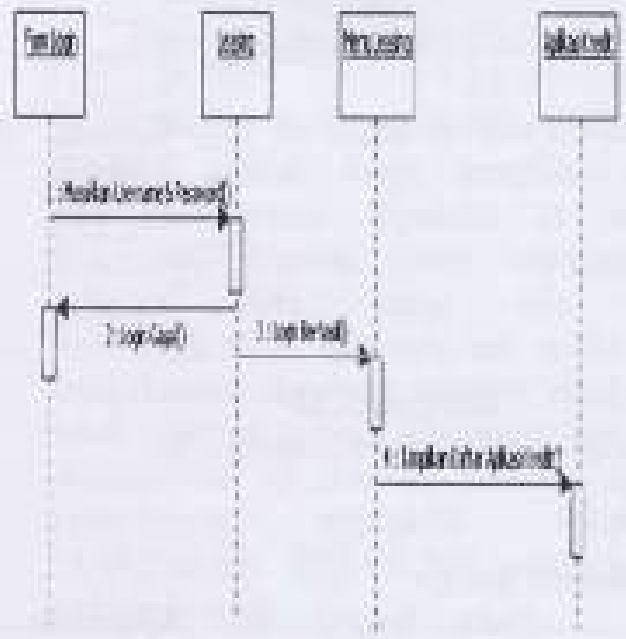

Gambar 3.12

Sequence Diagram Report Aplikasi Kredit

j. Sequence Diagram Repon Iklan Sequence diagram ini menjelaskan urutan proses melihat laporan iklan berdasarkan Cabang Autosafe dan Penjual umum, berikut gambarnya.

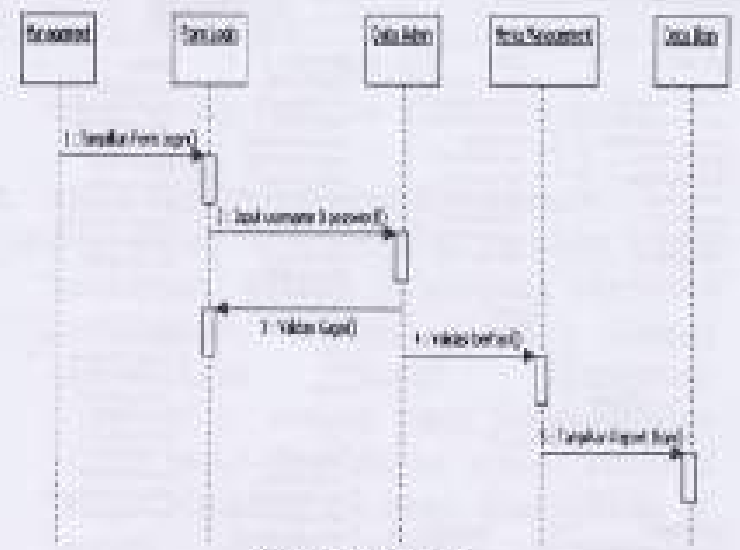

Gambar 3.13

Sequence Dlagram Reporz Iklan

k. Sequence Diagram Maintenance 
Sequence diagram ini menjelaskan urutan proses maintenance tabel-tabel yang ada di dalam database mobilkuhyundai yang dilakukan oleh Administrator, berikut gambarnya.

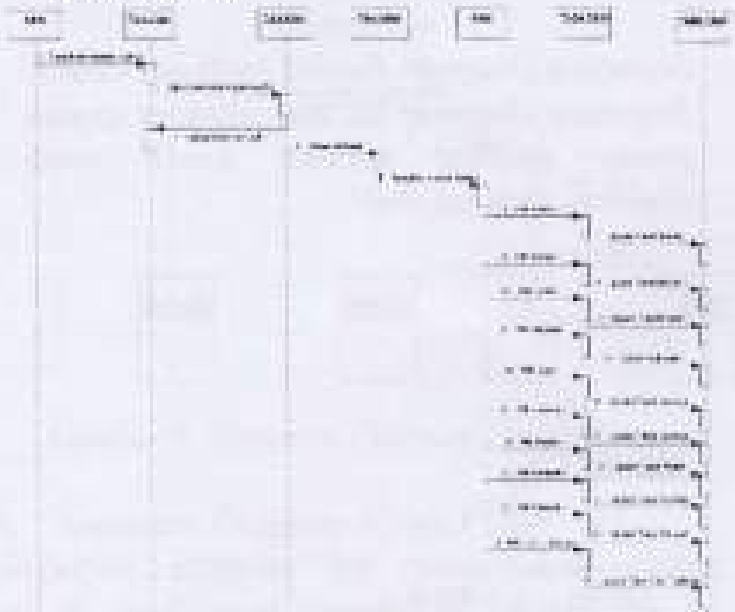

Gambar 3.14

Sequence Diagram Maintenance

\subsubsection{Database design}

Pada bagian ini dijelaskan mengenai perancangan fisik tabel-tabel yang diperlukan untuk perancangan sistem yang semuanya dikumpulkan dalam satu database, Desain database fisiknya adalah seperti tampak pada gambar 3.5, dan diagram tersebut digambar menggunakan bantuan perangkat lunak MySQL Workbench 5.05 .

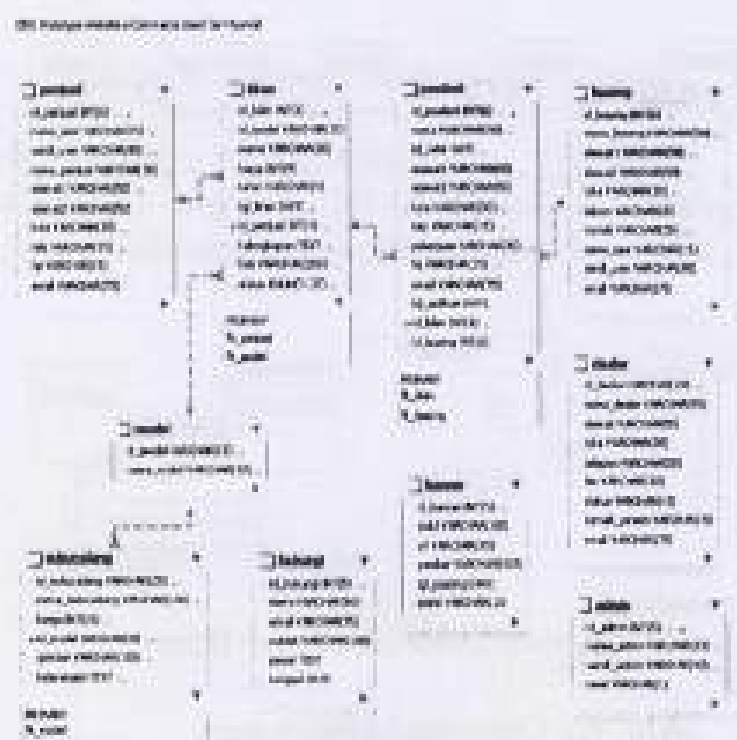

Gambar 3.26
Entity Relationship Diagram Sistem Keseluruhan 


\section{Hasil Dan Pembahasan 4.1 Hasil}

Pada bagian ini akan dijelaskan mengeaai hasil prototype website e-commence used car Hyundai, Uji coba ini menggunakan beberapa sample data yang dimasukkan untuk mengetahui apakah aplikasi yang telah dibaat dapat berjalan sebagaimana mestinya. Uji coba dilakukan langsung di website yang menjadi target studi kasus yaitu di alamat www.mobilkuhyundai,com sedangkan untuk sewa hosting dan domain menggunakan jasa penyedia layanan sewa hosting dan domain dari KIOSDOMAIN. Untuk tahap awal website ini mengambil paket starter dengan kapasitas hosting 50MB, bandividth per bulannya adalah 1GB.

\section{Akses Website Untuk Pengguna Umum}

Pada bagian ini dijelaskan mengenai hasil tampilan halaman web yang boleh diakses oleh pengguna atau pengunjung umum, dimana tidak diperlukan login untuk melihat informasi-informasi yang ada di dalamnya.

\section{a. Halaman Utama}

Setelah dijalankan oleh salah satu browser, tampilan balaman utams protyotype website e-commere used car Hyundai adalah seperti tampak pada gambar di bawah ini.

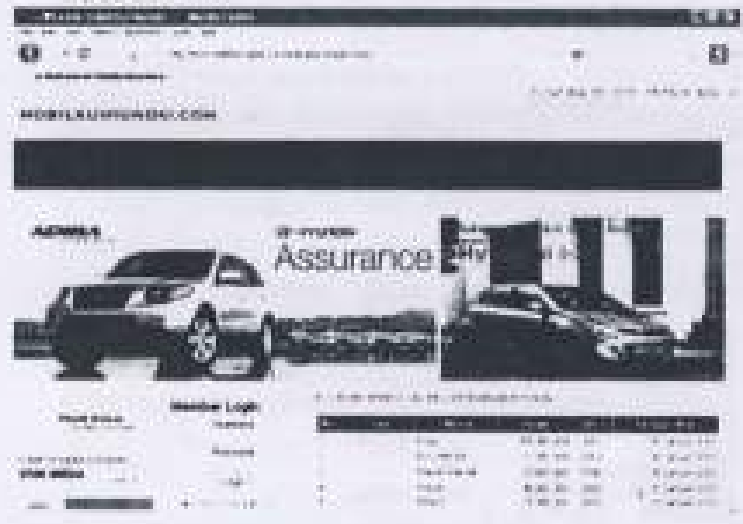

\section{Hasil Pencarian Suku Sadang}

Berikut adalah hasil pencarian info suku cadang yang diminta oleh pengunjung, sebagai contoh apabila pengunjung memasukkan kata kunci "Battery" maka seluruh data suku cadang yang mengandung kata "Battery" akan ditampilkan di layar. Halaman ini akan ditampilkan di bagian content apabila pengunjung mengklik hypperlink "Cek Harga Part Hyundai" yang ada di bagian footer.

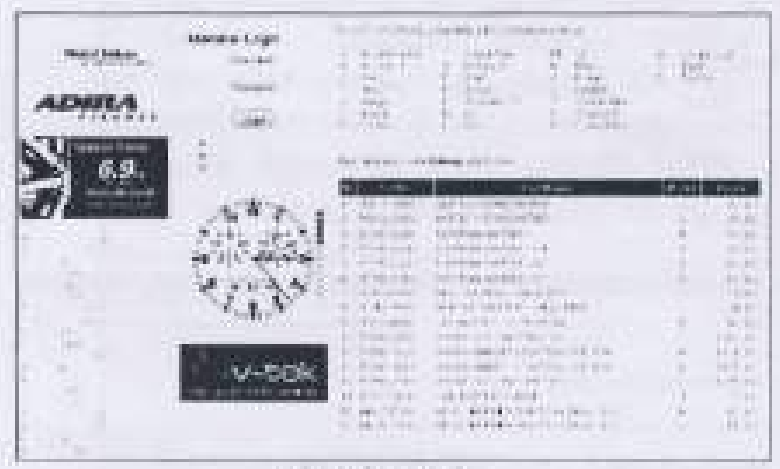

Gambar 4.3

Hasil Pencarian Suku Cadang

c. Hasil Daftar Jaringan Service Hyundai

Berikut adalah hasil tampilan daftar jaringan service Hyundai di seluruh Indonesia. Karena untuk menampilkan seluruh data yang ada tidak memungkinkan ditulisan ini, maka hasil tampilannya dipotong sampai dengan 18 baris recond saya. Halaman ini akan ditampilkan di bagian content apabili pengunjung mengklik hypperlink "JARINGAN SERVICEt" yang ada di bagian header.

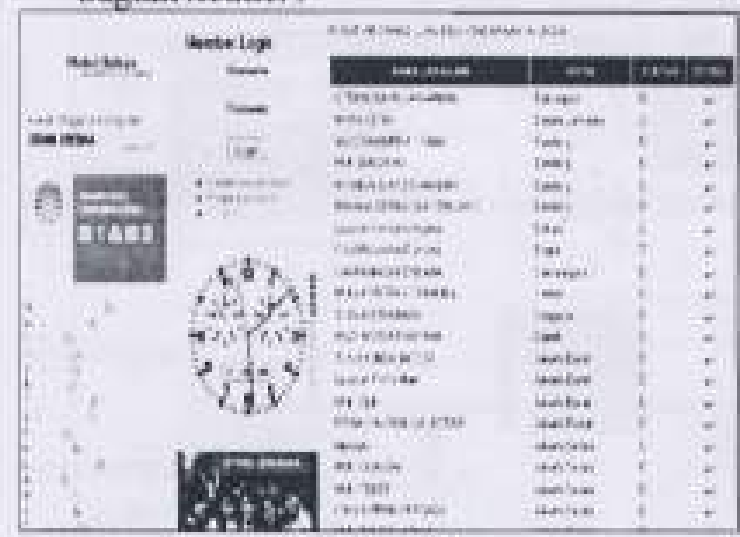

Gambar 4.4

Hasil Daftar Jaringan Service Hyundai

\section{d. Hasil Simulasi Kredit Kendaraan}

Berikut adalah hasil tampilan simulasi kredit kendaraan, dimana pengunjung mencoba melakukan simulasi kredit dengan memasukkan harga kendaraan $51,000,000$,- dengan uang muka sebesar $10,000,000$, dan jangka waktu kredit 3 tahun. Haluman ini akan ditampilkan di bagian content apabila pengunjung mengklik happerlink "Simulasi Kredit" yang ada di bagian footer. 


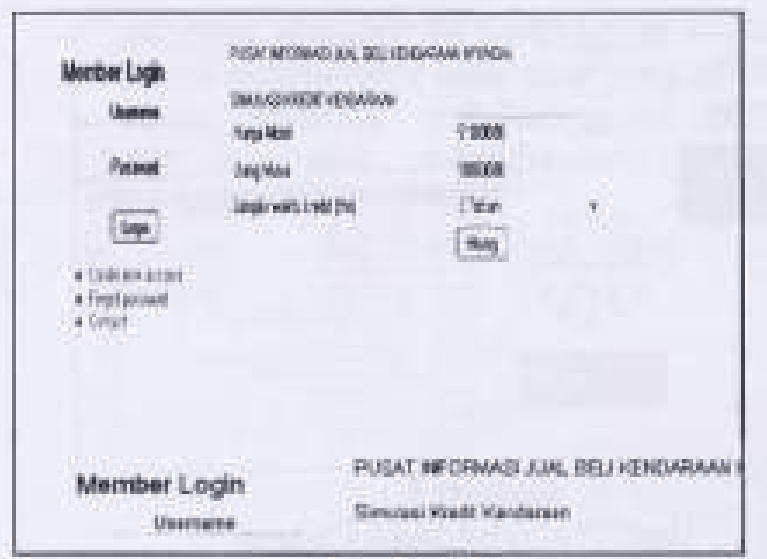

\section{Gambar 4.5}

Hasil Hasil Simulasi Kredit Kendaraan

c. Proses Aplikasi Kredit Kendaraan

Pertama pembeli melibat detail data kendaraan yang ingin dibeli, seperti tampak pada gambar di bawah, kemudian apabila kendaraan tersebut diminati dan ingin membeli secara kredit, maka pembeli bisa langsung mengklik hyperlink $\gg$ Proses Kredit $\ll<$ yang terdapat di bagian bawah detail kendaraan.

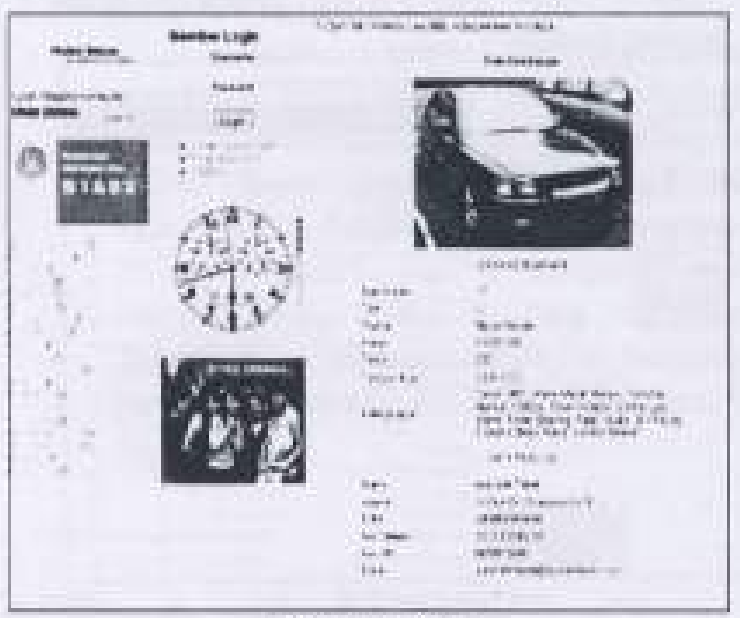

Gambar 4.6

\section{Detail Data Kendaraan}

Setelah pembeli menekan hyperlink $\gg>$ Proses Kredit $\ll$ maka kemudian pembeli diminta untuk mengisi form aplikasi kredit yang bentuk formuna adalah seperti tampak pada gambar 4.? di bawah ini.

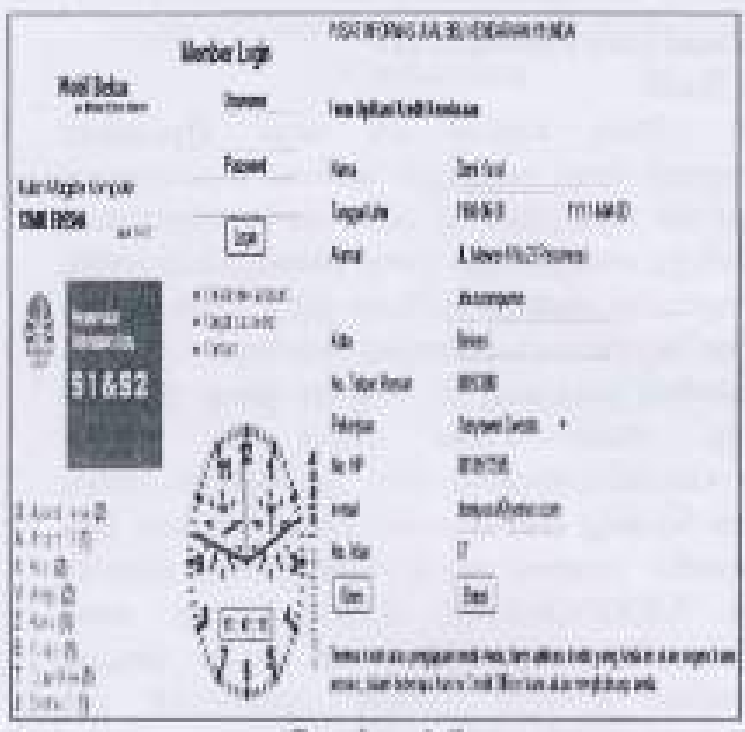

Gambar 4.7

Mengisi Aplikasi Kredit Kendaraan

\subsubsection{Akses Website Untuk Penjual}

Pada bagian ini dijelaskan mengenai hasil tampilan halaman web yang boleh diakses oleh penjual dan untuk melihat halaman web ini penjual harus melakukan login sesuai dengan akun yang dimilikinya. Sebelum memiliki menjadi member di mobilkulyyundai.com penjual harus mendaftar terlebih dahulu dengan mengisi form register seperti tampak pada gambar di bawah.

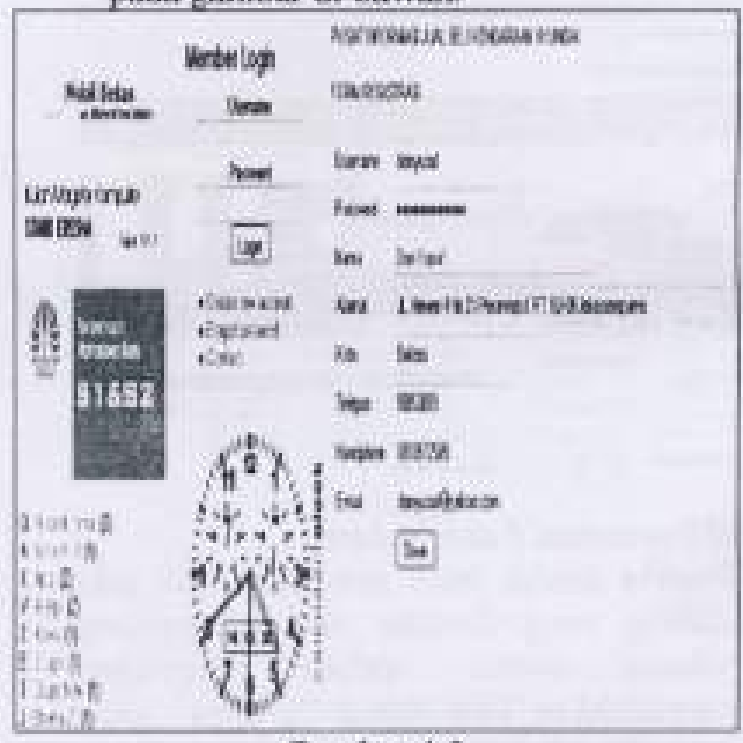

Gambar 4.8

Mengisi Fom Aplikasi Menjadi Member

a. Menu Penjual

Berikut adalah tampilan menu penjual yang telah bethasil melakukan logm sesuai dengan akun yang dimilikinya. Pada menu 
penjual ini terdapat beberapa hyperlink disebelah kiri yaitu: Pasang Iklan, Update Iklan, Update profile dan Logout. Sedangkan di bagian sebelah kanan adalah daftar iklan yang pernah dipusang olehnya

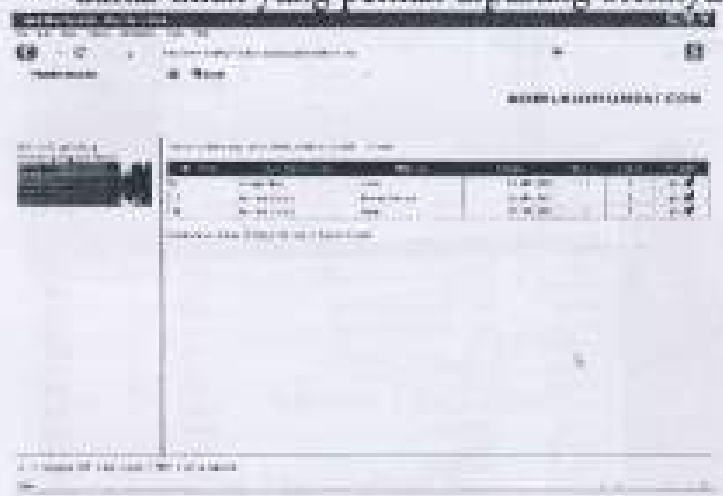

Gambar 4.9

\subsubsection{Akses Website Untuk Manajemen Autosafe}

Pada bagian ini dijelaskan mengenai hasil tampilan halaman web yang boleh diakses oleh penjual dan untuk melihat halaman web ini penjual harus melakukan login sesuai dengan akun yang dimilikinya.

a. Menu Manajemen Autosafe

Berikut adalah tampilan menu manajemen Autosafe yang telah berhasil melakukan login sesuai dengan akun yang dimilikinya. Pada menu manajemen Autosafe in beberapa hypertink disebelah kiri untuk melihat laporan pemasangan iklan cabang-cabang Autosafe dan Umum, serta form pencarian untuk melihat laporan iklan diantara dua tanggal sehingga laporannya bisa dilihat per mingguan, bulahan atau bahkan tahunan.
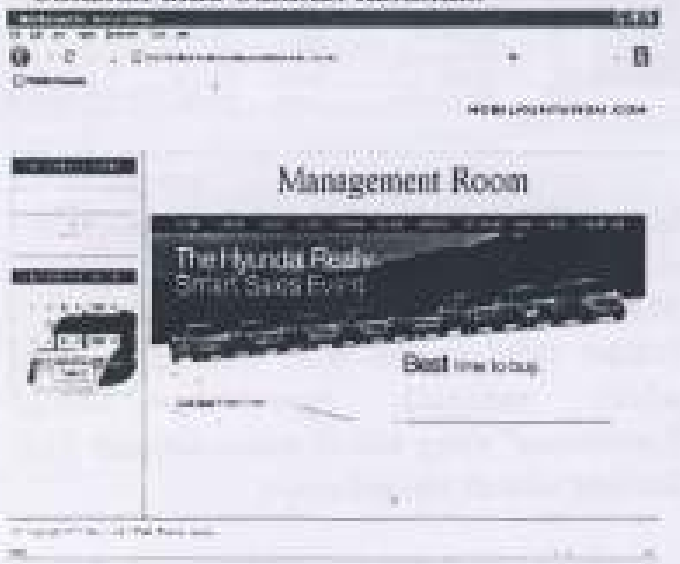

Gambar 4.11

Menu Manajemen Autosafe

b. Laporan Iklan per Cabang
Manajemen Autosafe dapat melihat laporan iklan per cabang atau iklan yang dipasang oleh penjual lainnya dengan cara mengklik hyperlink yang ada di bagian menu sebelah kiri. Berikut hasil tampilan laporan iklan per cabang.

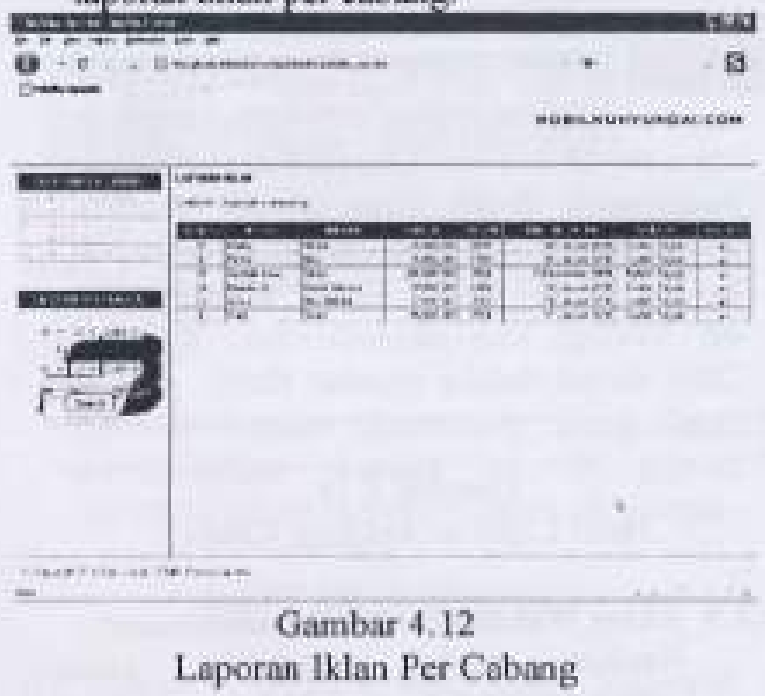

b. Laporan Iklan Per Tanggal

Manajemen Autosafe dapat melihat laporan iklan per tanggal dengan cara mengisi tanggal awal dan tanggal akhir laporan yang diminta kemudian mengklik tombol "Search". Berikut hasil tampilan laporan iklan per tanggal

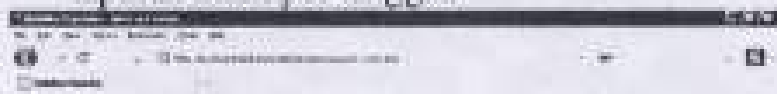

abenc num numearison

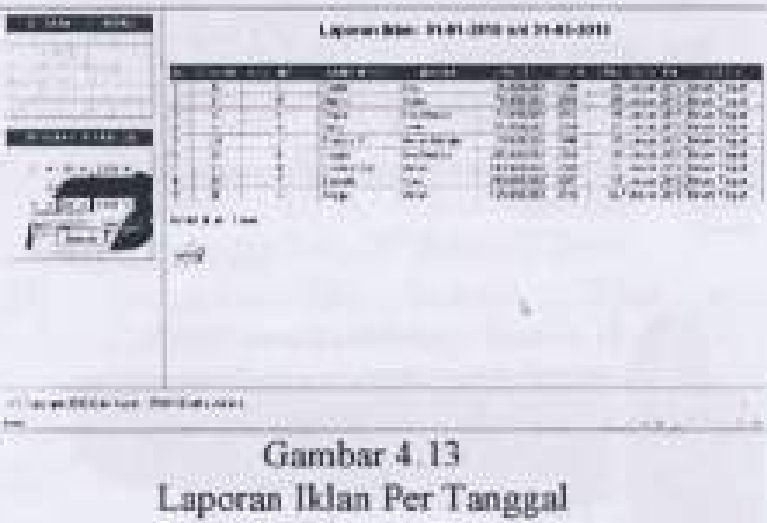

4.1.4 Akses Website Untuk Leasing

Berikut adalah tampilan menu leasing yang telah berhasil melakukan login sesuai dengan akun yang dimilikinya Pada menu leasing ini terdapat beberapa hyperlink disebelah kiri yaitu: Daftar Aplikast Kredit, Update Profile dan Logout. Sedangkan di bagian sebelah kanan adalah aplikasi 
kredit yang diajukan olch calon pembel secara online.
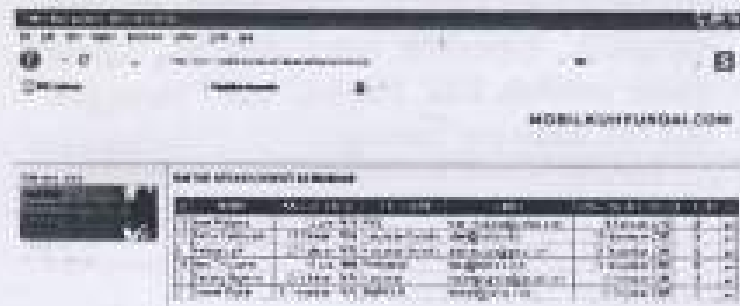

Gambar 4.14

Hasil Laporan Aplikasi Kredit

\subsubsection{Akses Wehsite Untuk Administrator}

Berikut adalah tampilan menu administrator yang telah berhasil melakukan login sesuai dengan akun yang dimilikinya. Pada menu administrator ini terdapat beberapa hyperiink disebelah kin yaitu: Master tabel-rabel yang dipakai dalam database untuk keperluan maintenance system.

a. Menu Admin

Berikut adalah tampilan menu admin yang telah berhasil melakukan login sesuai dengan akun yang dimilikinya. Pada menu admin ini beberapa hyperlink di sebelah kiri untuk mengupdute tabel-tabel yang ada di dalam database mobilkuhyundai.com

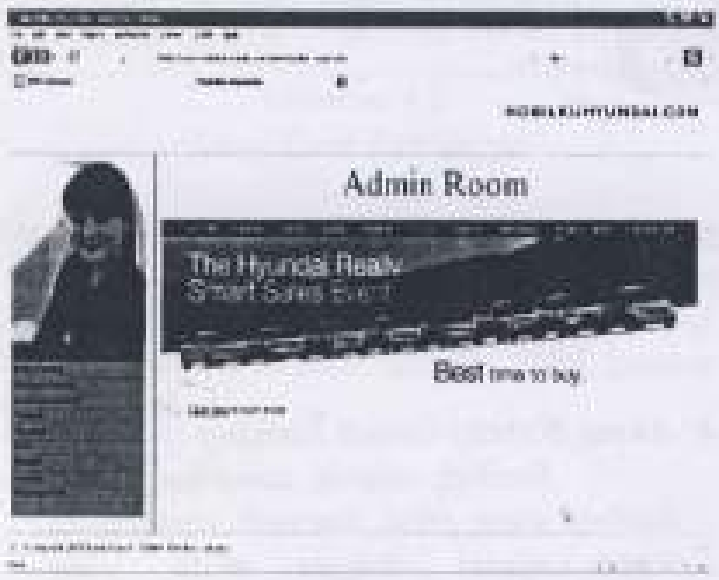

Gambar 4.15

Menu Administrator
Master tabel suku cadang akan muncul apabila admin mengkik hyperlink "Suku Cadang" yang ada di menu sebelah kiri. Berikut adalah tampilannya.
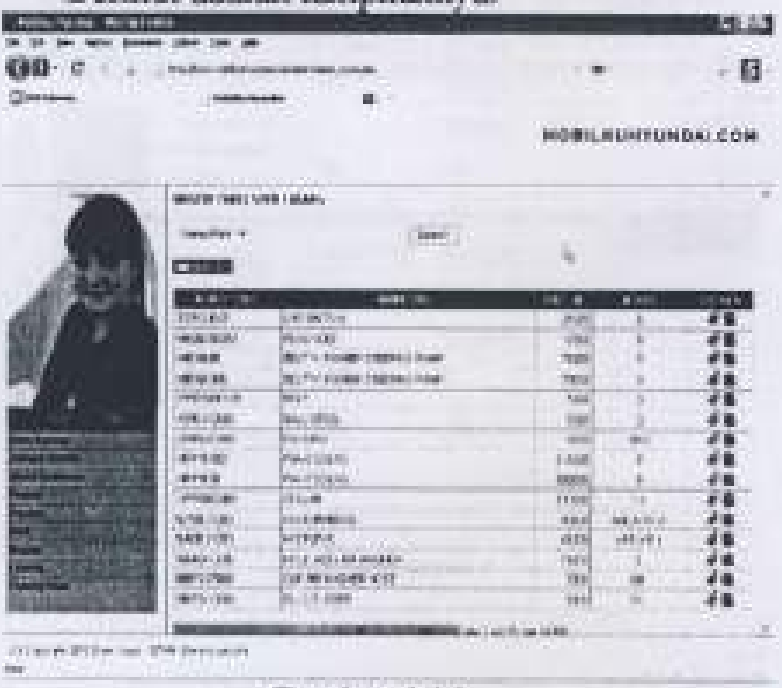

Gambar 4.16

Master Tabel Suku Cadang

\section{c. Master Jaringan Service}

Master tabel jaringan service akan muncul apabila admin mengkik hyperlink "Jaringan Service" yang ada di menu sebelah kiri. Berikut adalah tampilannya.
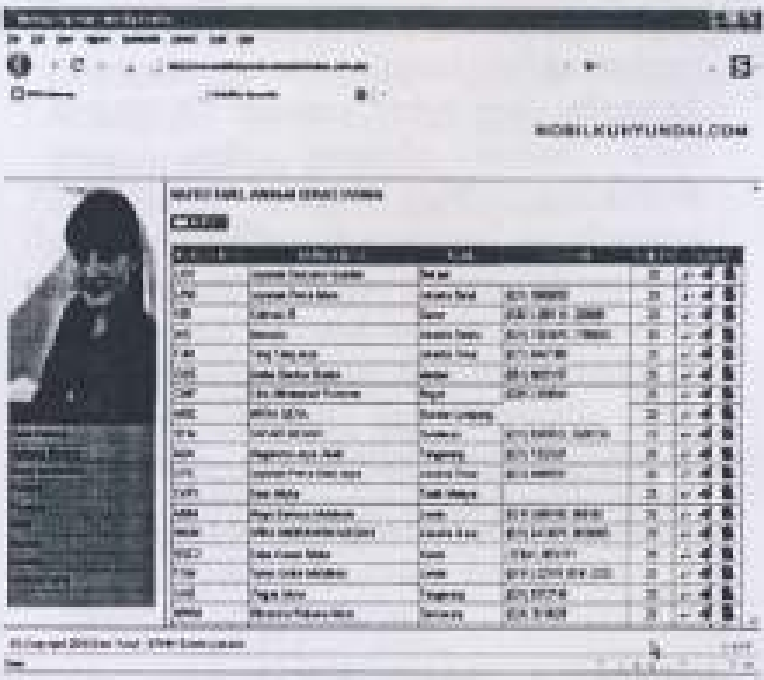

Gambar 4.17

Master Tabel Jaringan Service Hyundai

d. Master Model Kendaraan Hyundai

Master tabel model akan muncul apabila admin mengkik hyperlink "Model Kendaraan" yang ada di menu sebelah kiri. Berikut adalah tampilannya.

\section{b. Master Tabel Suku Cadang}




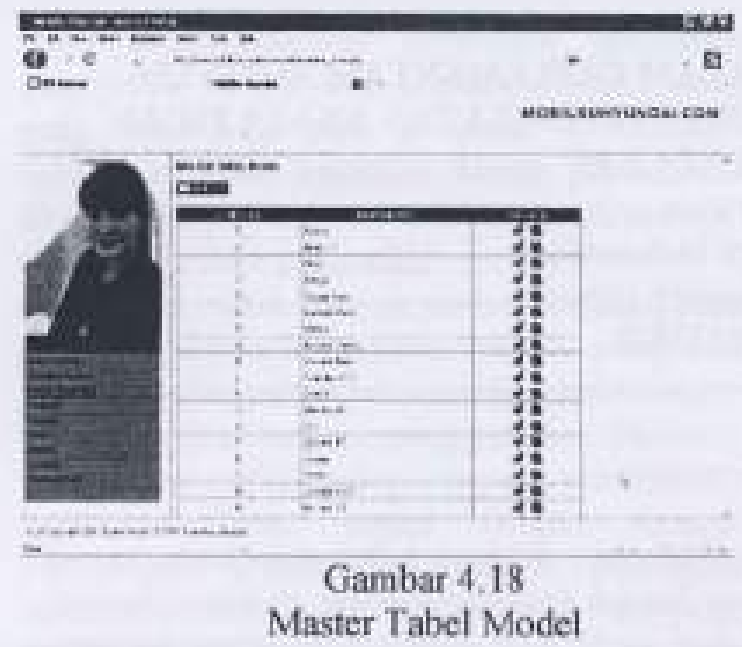

\section{Kesimpulan Dan Saran}

\section{$5.1 \quad$ Kesimpulan}

a. Faktor yang mempenguruhi konsumen untuk mengunjungi website jual beli mobil bekas adalah kemudahan pernakaian dan fitur-fitur informatif yang bermanfaat bagi penggunanya.

b. Model e-Commerce yang dibangun mampu memberikan kemudahan bagi pemilik kendaraan Hyundai untuk menjual kendaraannya secara online melalui media web.

c. Program aplikasi web e-Commerce yang dibsat terbukti valid dan mampo Memberikan kemudahan bagi pencari mobil bekas yang ingin membeli kendaraan merk Hyundai baik secara kontak maupun kredit, sehingga tidak perlu lagi datang ke showroom-showroom mobil.

d. Meningkatkan kepercayaan konsumen dalam bertransaksi secara online dapat dilakukan dengan memberikan rating dan komentar terhadap produk yang ditawarkan.

\subsection{Saran}

a. Perlunya untuk selalu mengupdate website secara berkala agar tidak ditinggal oleh pengunjungnya. b. Perlunya SDM yang dapat menangani dan mengatur e-Commerce agar berjalan dengan baik.

c. Perhatian terhadap sistem yang baik juga menjadi prioritas utama dalam mengembangkan aplikasi e-Commerce. Sebagai contohnya adalah memperhatikan security (keamanan aplikasi). Bisa dibuat di dalam sistem itu sendiri ataupun bekerja sama dengan penyodia jasa keamanan web.

d. Banyak faktor yang dapat dilanjutkan didalam penelitian ini, selain dari aspek Management dan sistem bisa dilihat didalam perkembangan dari aplikasi itu sendiri. Salah satunya adalah teknik SEO (Search Engine Optimized), yang dapat menampilkan website ini di jajaran terdepan dalam mesin pencarian di google.

\section{DAFTAR PUSTAKA}

[1] Joe F. George, Dinesh Batra, Joseph S. Valacich, Jeffery A. Hoffer, Object Oriented Analysis System and Design Second Edition, Pearson International Edition, New York, 2009

[2] Jeffrey A. Hoffer, Marry B. Prescott, Fred R. McFadden, Modern Database Management - Eighth Edition, Pearson International Edition, New York, 2007

[3] Huff, Sid L. Michael Wade, Scott Schneberger, "Cases ini Electronic Commence", Second Edition, USA: MoGinaw Hill, 2002

[4] Greenstein, Marilyn, and Miklos Vasarhelyi., "Electronic Commerce: Security, Risk Management, and Control", USA The McGraw Hill Companies Inc., 2 ${ }^{\text {vd }}$ Edition, 2002.

[5] Richardus Eko Indrajit, "Kiat eCommence dan Strategi Bisnis di Dunia Maya", Gramedia, Jakarti. 2001.

[6] Riycke Ustadiyanto, "Frumework eCommerce", Andi. 2001. 